\section{The Use of N-6-benzyladenine to Regulate Flowering of Phalaenopsis Orchids}

\author{
Po-Hung Wu and Doris C.N. Chang ${ }^{1}$
}

ADDITIONAL INDEX wORDs. spiking percentage, flower quality, growth regulation, N-6-benzyladenine (BA), doritaenopsis

Summary. Phalaenopsis orchid (Phalaenopsis hybrids) is an important potted flower around the world. Programming phalaenopsis to bloom as needed and improving flower quality are important to increasing profitability. Whole plants were sprayed with $70 \mathrm{mg} \cdot \mathrm{L}^{-1} \mathrm{~N}$-6-benzyladenine $(\mathrm{BA})$ at dusk on days 1 and 14 after subjecting them to a $26 / 18^{\circ} \mathrm{C}$ treatment. The spiking percentage at week 4 after the start of the $26 / 18^{\circ} \mathrm{C}$ treatment of phalaenopsis Luchia Pink ' $244^{\prime}$ ' control plants was $58 \% \pm$ $12 \%($ mean $\pm \mathrm{SE})$, while $98 \% \pm 4 \%$ of the BA-treated plants developed floral spikes. The number of flower spikes in phalaenopsis Luchia Pink '244' and doritaenopsis orchid (Doritaenopsis hybrids) Taisico Firebird 'OX' increased from 1 to 1.2 flower spikes per plant and from 1.6 to 2 flower spikes per plant at the end of week 14, respectively. When whole plants were sprayed with $150 \mathrm{mg} \cdot \mathrm{L}^{-1} \mathrm{BA}$ at dusk on day 1 of cooling, the number of flower spikes in phalaenopsis Sogo Yukidian 'V3' increased from 1.3 to 2 flower spikes per plant, and the flower count in phalaenopsis Tai Lin Redangel 'Queen' increased from 10.4 to 14 flowers at the end of week 20. However, the flower longevity of phalaenopsis Sogo Yukidian 'V3' and phalaenopsis Tai Lin Redangel 'Queen' was not affected. However, phalaenopsis Luchia Pink ' 244' sprayed with $70 \mathrm{mg} \cdot \mathrm{L}^{-1}$ BA on days 1 and 14 resulted in deformed flower spikes. It is recommended that 14 to 16 weeks before specific festivals, the phalaenopsis orchids should be put into $26 / 18^{\circ} \mathrm{C}$ and $\mathrm{BA}$ treatments (100-150 $\left.\mathrm{mg} \cdot \mathrm{L}^{-1}\right)$ at day 1 for commercial phalaenopsis orchids production. However, perhaps $\mathrm{BA}$ is not effective for all cultivars.

$\mathrm{P}$ halaenopsis is the most important potted orchid around the world, with a fast-growing market (Wang, 2004). It is a monopodial epiphytic orchid, having indeterminate inflorescences. Phalaenopsis spike (bolt) and bloom under conditions of proper temperature and light after the plants have matured (Lee and Lin, 1984; Wang, 1995). The potential flower spikes usually emerge at the axils of the third and/or fourth basipetal mature leaf (Lee and Lee, 1996).

Phalaenopsis can only be sold on the retail market when in bloom. The ability of phalaenopsis to spike and bloom under inductive environmental conditions is highly correlated with its leaf size, but there is a significant difference among various hybrids (Lee, 1991). It is important to program phalaenopsis to bloom when the market demand is the greatest, such as at Chinese New Year,

We thank OX ORCHIDS for providing plant materials and greenhouses during the experiment.

Department of Horticulture, National Taiwan University, No 1, Sec. 4, Roosevelt Road, 106, Taipei, Taiwan

${ }^{1}$ Corresponding author. E-mail: hyha@ntu.edu.tw.
Valentine's Day, Mother's Day, Christmas, etc.

The period from spiking to first open bloom is unaffected by factors such as lighting, photoperiodism, and fertilizer when the temperature is held constant (Lin and Lee, 1998; Wang and Hsu, 1994). Because spiking precedes flowering in phalaenopsis, controlling spiking becomes the focus for the effective control of the flowering time of this orchid. The application of plant growth substance may be one solution to controlling spiking (Wang, 1995). Phalaenopsis is unable to spike and bloom at high temperatures (Lee and Lin, 1984; Wang et al., 2006). If a spiked phalaenopsis plant is moved to a high-temperature environment $\left(30^{\circ} \mathrm{C}\right)$ before its inflorescence differentiation, it will not produce flowers. This situation may be related to the decline of gibberellic acids (GAs) and cytokinin concentration in the developing flower stem (Chen et al., 1994; Chou et al., 2000). Using plant growth substances such as $\mathrm{GA}_{3}$ or N-6-benzyladenine (BA) separately at high temperatures failed to induce phalaenopsis to spike or bloom (Chen et al., 1994, 1997; Kubota et al., 1997). However, Chen et al. (1994) injection of $\mathrm{GA}_{3}$ into phalaenopsis plants that had already developed 3- to 5-cm-long floral spikes initialed at a cooler temperature resulted in flowering at high temperature $\left(30^{\circ} \mathrm{C}\right)$.

At lower temperatures $(25 / 20$ ${ }^{\circ} \mathrm{C}$ ), treating phalaenopsis with $\mathrm{GA}_{3}$ resulted in long flower spikes and higher flower count. However, the petals are relatively thin, and lopsided flowers are easily generated (Lin, 1994). Spraying phalaenopsis with $\mathrm{BA}$ at a low temperature resulted in more flowers and flower spikes (Ho and Yang, 1990; Lin, 1994). Spraying $\mathrm{BA}$ on phalaenopsis when the first visible flower bud occurs led to more flowers with larger flower diameters and relatively thicker petals. However, the percentage of flower bud abortion increased (Lin, 1994).

The objective of this study was to investigate the feasibility of using $\mathrm{BA}$ in the regulation of phalaenopsis flowering to increase the spiking percentage, the spike, and flower count of phalaenopsis.

\section{Materials and methods}

EXPT. 1: EFFECT OF BA ON SPIKING PERCENTAGE AND FLOWER COUNT. Plants of two commercial phalaenopsis cultivars were selected, including phalaenopsis Luchia Pink '244' and doritaenopsis Taisico Firebird 'OX'. Mature plants (six leaves and the leaf spread was $25-30 \mathrm{~cm}$ ) used in this experiment were grown in $10.5-\mathrm{cm}$-diameter pots (volume of $650 \mathrm{~mL}$ ) that were filled with Chilean

\begin{tabular}{llll}
\hline $\begin{array}{l}\text { Units } \\
\begin{array}{l}\text { To convert U.S. to SI, } \\
\text { multiply by }\end{array}\end{array}$ & U.S. unit & SI unit & $\begin{array}{l}\text { To convert SI to U.S., } \\
\text { multiply by }\end{array}$ \\
\hline 29.5735 & $\mathrm{fl} \mathrm{oz}$ & $\mathrm{mL}$ & 0.0338 \\
2.54 & inch $(\mathrm{es})$ & $\mathrm{cm}$ & 0.3937 \\
7.4892 & $\mathrm{oz} / \mathrm{gal}$ & $\mathrm{g} \cdot \mathrm{L}-1$ & 0.1335 \\
1 & $\mathrm{ppm}$ & $\mathrm{mg} \cdot \mathrm{L}-1$ & 1 \\
$\left({ }^{\circ} \mathrm{F}-32\right) \div 1.8$ & ${ }^{\circ} \mathrm{F}$ & ${ }^{\circ} \mathrm{C}$ & $\left(1.8 \times{ }^{\circ} \mathrm{C}\right)+32$
\end{tabular}


Table 1. Reproductive growth of phalaenopsis Luchia Pink '244' and doritaenopsis Taisico Firebird 'OX' orchids that were sprayed with $70 \mathrm{mg} \cdot \mathrm{L}^{-1} \mathrm{~N}-6$-benzyladenine $(\mathrm{BA})$ on days 1 and 14 after low temperature treatment $\left(26 / 18{ }^{\circ} \mathrm{C}\right) .^{\mathrm{z}}$

\begin{tabular}{|c|c|c|c|c|c|c|c|}
\hline \multirow[b]{2}{*}{ Cultivar } & \multirow{2}{*}{$\begin{array}{c}\text { BA } \\
\text { treatment } \\
\left(70 \mathrm{mg} \cdot \mathrm{L}^{-1}\right)^{\mathrm{y}}\end{array}$} & \multicolumn{2}{|c|}{$\begin{array}{c}\text { Spiking percentage } \\
\text { after cooling } \\
{[\text { mean } \pm \text { SE }(\%)]}\end{array}$} & \multicolumn{2}{|c|}{$\begin{array}{l}\text { Flower spikes } \\
\text { (no./plant) }\end{array}$} & \multirow{2}{*}{$\begin{array}{c}\text { Spike deformity } \\
{[\text { mean } \pm \text { SE }(\%)]} \\
\text { Week } 14\end{array}$} & \multirow{2}{*}{$\begin{array}{c}\text { Flowers } \\
\text { (no./plant) } \\
\text { Week } 14\end{array}$} \\
\hline & & Week 4 & Week 14 & Week 4 & Week 14 & & \\
\hline Pink '244' & Yes & $98 \pm 4$ & $100 \pm 0$ & $1.2 \mathrm{a}$ & $1.2 \mathrm{a}$ & $43 \pm 19$ & $8.5 \mathrm{a}$ \\
\hline Doritaenopsis Taisico & No & $100 \pm 0$ & $100 \pm 0$ & $1.5 \mathrm{~b}$ & $1.6 \mathrm{~b}$ & $0 \pm 0$ & $11.3 \mathrm{a}$ \\
\hline
\end{tabular}

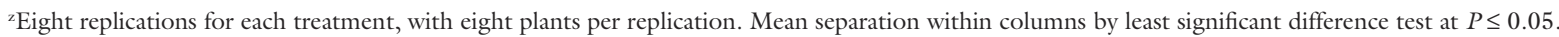

${ }^{y} 1 \mathrm{mg} \cdot \mathrm{L}^{-1}=1 \mathrm{ppm}$.

sphagnum moss as the sole growing substrate. They were grown from 4 Mar. 2003 to 1 Sept. 2004 in a greenhouse with an average daytime temperature of $28{ }^{\circ} \mathrm{C}$, an average night temperature of $23^{\circ} \mathrm{C}$, an average photosynthetic photon flux $(P P F)$ at $300 \mu \mathrm{mol} \cdot \mathrm{m}^{-2} \cdot \mathrm{s}^{-1}$ (maximum 400 $\mu \mathrm{mol} \cdot \mathrm{m}^{-2} \cdot \mathrm{s}^{-1}$ at noon), and a $12-\mathrm{h}$ photoperiod. Plants were fertigated once weekly, alternating 0.2 and $0.5 \mathrm{~g} \cdot \mathrm{L}^{-1}$ of $20 \mathrm{~N}-8.6 \mathrm{P}-16.6 \mathrm{~K}$ water-soluble fertilizer (Peters; Scotts, Marysville, $\mathrm{OH}$.

On 1 Sept. 2004, plants were moved into a greenhouse regulated to $26^{\circ} \mathrm{C}$ day and $18{ }^{\circ} \mathrm{C}$ night, with an average $P P F$ at $500 \mu \mathrm{mol} \cdot \mathrm{m}^{-2} \cdot \mathrm{s}^{-1}$ (maximum $800 \mu \mathrm{mol} \cdot \mathrm{m}^{-2} \cdot \mathrm{s}^{-1}$ at noon) and a $12-\mathrm{h}$ photoperiod. Plants were fertigated weekly with $0.3 \mathrm{~g} \cdot \mathrm{L}^{-1} 10 \mathrm{~N}-$ 12.9P-16.6K water-soluble fertilizer (Peters), and they were sprayed biweekly with $1 \mathrm{~g} \cdot \mathrm{L}^{-1} 10 \mathrm{~N}-12.9 \mathrm{P}-$ $16.6 \mathrm{~K}$ water-soluble fertilizer at $\approx 1500 \mathrm{HR}$. On days 1 and 14 after they were moved into the cool room, they were sprayed to drip with about $10 \mathrm{~mL}$ of a solution containing 70 $\mathrm{mg} \cdot \mathrm{L}^{-1}$ BA (Sigma, St. Louis) and 0.05\% Tween 20 (Sigma) at dusk. The powder of $\mathrm{BA}$ was dissolved in $1 \mathrm{~N} \mathrm{NaOH}$ and was diluted for spraying. There were eight replications per treatment, each having eight plants. Most phalaenopsis hybrids could spike within 4 weeks of $26 / 18$ ${ }^{\circ} \mathrm{C}$ treatment and have the first open bloom before week 14. Therefore, we collected data on spiking percentage, spike number in weeks 4 and 14 after the treatment, flower count, and spike deformity on week 14 . The least significant difference (LSD) test was used for comparing treatment effects.

EXPt. 2: EFFECT OF BA ON SPIKING AND FLOWER QUALITY. Two cultivars, phalaenopsis Tai Lin Redangel 'Queen' and phalaenopsis Sogo Yukidian 'V3', were cultured similar to those in the above experiment. Plants were moved to a greenhouse on 6 Sept. 2005 for the lowtemperature treatment $\left(26 / 18{ }^{\circ} \mathrm{C}\right.$, $500 \mu \mathrm{mol} \cdot \mathrm{m}^{-2} \cdot \mathrm{s}^{-1} P P F$, and a $12-\mathrm{h}$ photoperiod). The leaves were sprayed with $0,50,100$, or $150 \mathrm{mg} \cdot \mathrm{L}^{-1} \mathrm{BA}$ at dusk. All solutions had $0.05 \%$ Tween-20. The spray solutions were used at an average of $10 \mathrm{~mL}$ per plant. There were eight replications, each having four plants. We recorded the date of anthesis, flower spike number, flower count, flower diameter on week 14, and flower longevity after the first flower started to wilt. LSD test was used for comparing treatment effects.

\section{Results and discussion}

In Expt. 1, spraying $70 \mathrm{mg} \cdot \mathrm{L}^{-1}$ BA on whole plants on days 1 and 14 after the low-temperature treatment increased the spiking percentage of phalaenopsis Luchia Pink '244' from $58 \% \pm 12 \%$ (mean \pm SE) to $98 \% \pm 4 \%$ by the end of the 4th week (Table 1). These results indicated that BA could accelerate the spiking of phalaenopsis and be scheduled for specific festivals. All plants bloomed after 14 weeks. The flower spike numbers of phalaenopsis Luchia Pink '244' and doritaenopsis Taisuco Firebird 'OX' plants treated with BA increased from 1 to 1.2 flower spikes per plant and from 1.6 to 2 flower spikes per plant, respectively, in week 14 (Table 1 ). This result was similar to that of spraying 50 to 150

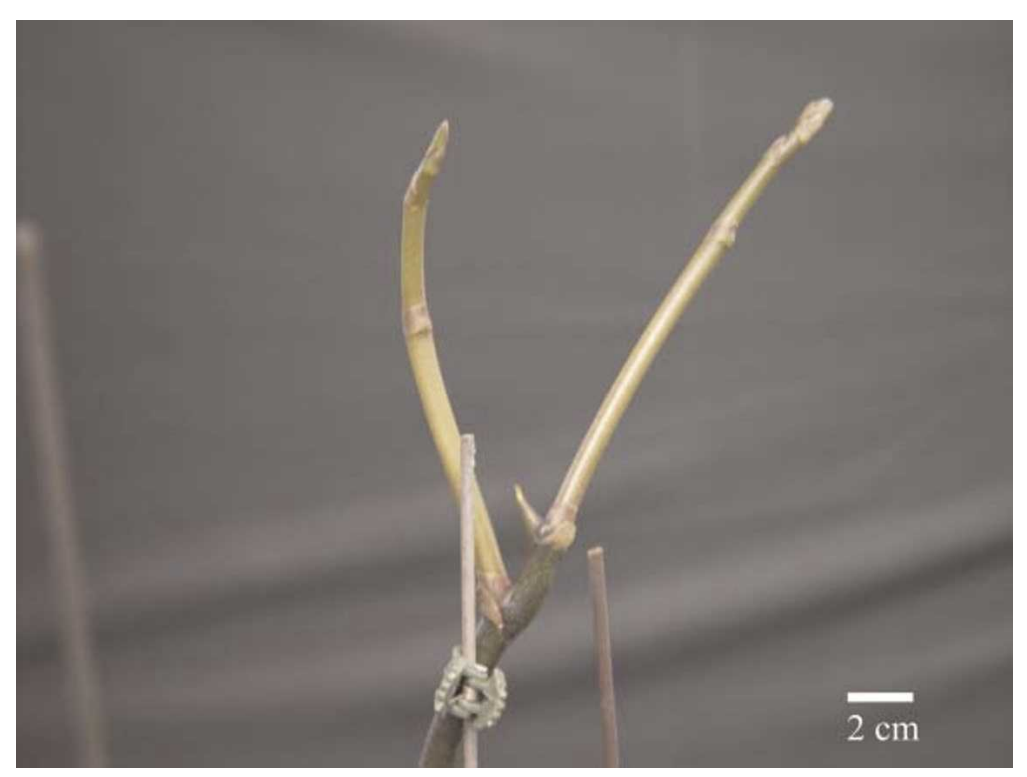

Fig. 1. Deformed flower spike of phalaenopsis Luchia Pink ' 244 ' orchid that was caused by spraying $70 \mathrm{mg} \cdot \mathrm{L}^{-1} \mathrm{~N}-6$-benzyladenine on days 1 and 14 after low temperature treatment $\left[26 / 18^{\circ} \mathrm{C}\left(78.8 / 64.4^{\circ} \mathrm{F}\right)\right] ; 1 \mathrm{mg} \cdot \mathrm{L}^{-1}=1 \mathrm{ppm}$, $1 \mathrm{~cm}=0.3937$ inch. 
Table 2. Flower spike number and flower quality of phalaenopsis Tai Lin Redangel 'Queen' and phalaenopsis Sogo Yukidian 'V3' orchids as affected by the spraying of various concentrations of N-6-benzyladenine (BA) on the 1 of low temperature treatment $\left(26 / 18^{\circ} \mathrm{C}\right) .^{\mathrm{z}}$

\begin{tabular}{|c|c|c|c|c|c|c|c|}
\hline Cultivar & $\begin{array}{l}\text { BA concn } \\
\left(\mathrm{mg} \cdot \mathrm{L}^{-1}\right)^{\mathrm{y}}\end{array}$ & $\begin{array}{c}\text { Time to } \\
\text { anthesis }(\mathrm{d})\end{array}$ & $\begin{array}{c}\text { Flower spikes } \\
\text { (no./plant) }\end{array}$ & $\begin{array}{l}\text { Flower spike } \\
\text { length }(\mathrm{cm})^{\mathrm{x}}\end{array}$ & $\begin{array}{c}\text { Flowers } \\
\text { (no./plant) }\end{array}$ & $\begin{array}{c}\text { Flower } \\
\text { diam }(\mathrm{cm})\end{array}$ & $\begin{array}{c}\text { Flower } \\
\text { longevity }(d)\end{array}$ \\
\hline Phalaenopsis Tai Lin & 0 & $139.4 \mathrm{a}$ & $1.1 \mathrm{a}$ & 80.9 a & $10.4 \mathrm{~b}$ & $10.3 \mathrm{a}$ & $101.3 \mathrm{a}$ \\
\hline \multirow[t]{3}{*}{ Redangel ‘Queen’ } & 50 & $138.1 \mathrm{a}$ & $1.3 \mathrm{a}$ & $80 \mathrm{a}$ & $11.1 \mathrm{ab}$ & $9.8 \mathrm{a}$ & $105 \mathrm{a}$ \\
\hline & 100 & $135.8 \mathrm{a}$ & $1.1 \mathrm{a}$ & $81 \mathrm{a}$ & $11.1 \mathrm{ab}$ & $10 \mathrm{a}$ & $103 \mathrm{a}$ \\
\hline & 150 & $135.9 \mathrm{a}$ & $1.5 \mathrm{a}$ & $84.4 \mathrm{a}$ & $14 \mathrm{a}$ & $9.7 \mathrm{a}$ & $101.3 \mathrm{a}$ \\
\hline Doritaenopsis & 0 & $108.3 \mathrm{a}$ & $1.3 \mathrm{~b}$ & $65.3 \mathrm{a}$ & $10.1 \mathrm{a}$ & $11.2 \mathrm{a}$ & $125.9 \mathrm{a}$ \\
\hline & 150 & $98 \mathrm{~b}$ & $2 \mathrm{a}$ & $57.1 \mathrm{a}$ & $12.1 \mathrm{a}$ & $10.4 \mathrm{a}$ & $126.8 \mathrm{a}$ \\
\hline
\end{tabular}

${ }^{2}$ Eight replications for each treatment, with four plants per replication. Mean separation within columns by least significant difference test at $P \leq 0.05$

$1 \mathrm{mg} \cdot \mathrm{L}^{-1}=1 \mathrm{ppm}, 1 \mathrm{~cm}=0.3937$ inch.

$\mathrm{mg} \cdot \mathrm{L}^{-1} \mathrm{BA}$ in week 2 after the lowtemperature treatment began (Lin, 1994). However, the increased bud abortion observed by Lin (1994) was not found in this experiment. This may be caused by the different cultivar, culture technique, and the timing of $\mathrm{BA}$ treatment and its concentrations.

It was reported that spraying 50 to $150 \mathrm{mg} \cdot \mathrm{L}^{-1} \mathrm{BA}$ on whole plants in week 2 after the low-temperature treatment had began and also when the first floret bud was visible increased the flower count of Phalaenopsis amabilis and phalaenopsis Taisuco Bright (Lin, 1994). However, in the present experiment, spraying $70 \mathrm{mg} \cdot \mathrm{L}^{-1} \mathrm{BA}$ on whole plants on days 1 and 14 after the low-temperature treatment did not increase the flower count of doritaenopsis Taisico Firebird 'OX', although some plants bore three flower spikes but had only one to two flowers on each spike. The total flower count of this cultivar was less than that of the plants with a single spike [ 11.3 and 8.2 flowers per plant, respectively (Table 1)]. In addition, the use of BA upon phalaenopsis Luchia Pink '244' caused seriously forked spikes (Fig. 1). This abnormality appeared to be the result of a reduced apical dominance in spike. These results suggested that while the proper use of BA may increase the timeliness of spiking and the increase of flower spikes, more spikes may not result in a higher flower count, and the use of BA may cause spike deformity.

The results of Expt. 2 indicated that foliar application of $150 \mathrm{mg} \cdot \mathrm{L}^{-1}$ BA on phalaenopsis Tai Lin Redangel
'Queen' increased the flower count (from 10.4 to 14 flowers per plant), but not flower spike number and length or flower diameter (Table 2). However, foliar application of 150 $\mathrm{mg} \cdot \mathrm{L}^{-1} \mathrm{BA}$ on phalaenopsis Sogo Yukidian 'V3' increased the flower spike number from 1.3 to 2 flower spikes per plant and accelerated anthesis. None of the treatments resulted in bud abortion. The results showed that application of BA may increase the spike number or flower count in some phalaenopsis cultivars, but not the others. There was no flower spike deformity in Expt. 2, which may be due to different phalaenopsis cultivars and different treatment periods of BA.

\section{Conclusions}

Foliar application of $70 \mathrm{mg} \cdot \mathrm{L}^{-1}$ BA on whole plants on days 1 and 14 after the low-temperature treatment accelerated spiking by the end of the 4 th week. The number of flower spikes in phalaenopsis Luchia Pink '244' and doritaenopsis Taisico Firebird ' $O X$ ' were also increased by BA treatment. Spraying $150 \mathrm{mg} \cdot \mathrm{L}^{-1} \mathrm{BA}$ on whole plants on day 1 of the lowtemperature treatment increased the number of flower spikes in phalaenopsis Sogo Yukidian 'V3' and the flower count in phalaenopsis Tai Lin Redangel 'Queen' without affecting flower longevity. However, BA may cause flower spike deformity in some phalaenopsis cultivars. It is recommended that 14 to 16 weeks before specific festivals, the phalaenopsis orchids should be put into $26 / 18{ }^{\circ} \mathrm{C}$ and BA treatments $\left(100-150 \mathrm{mg} \cdot \mathrm{L}^{-1}\right)$ at day $\mathrm{l}$ for commercial phalaenopsis orchids production. However, BA may not be not effective for all cultivars.

\section{Literature cited}

Chen, W.S., H.W. Chang, W.H. Chen, and Y.S. Liu. 1997. Gibberellic acid and cytokinin affect Phalaenopsis flower morphology at high temperature. HortScience 32:1069-1073.

Chen, W.S., H.Y. Liu, Z.H. Liu, L. Yang, and W.H. Chen. 1994. Gibberellin and temperature influence carbohydrate content and flowering in Phalaenopsis. Physiol. Plant. 90:391-395.

Chou, C.C., W.S. Chen, K.L. Huang, H.C. Yu, and L.J. Liao. 2000. Changes in cytokinin level of Phalaenopsis leaves at high temperature. Plant Physiol. Biochem. 38:309-314.

Ho, F.W. and L. Yang. 1990. Effects of plant growth regulators on the growth and flowering of Phalaenopsis. Annu. Rept. Taiwan Sugar Res. Inst. 1989-90: $17-18$.

Kubota, S., H. Hamotsu, I. Kazuo, and K. Masaju. 1997. Effect of light condition and $\mathrm{GA}_{3}$ application on development of axillary buds during low temperature treatment in Phalaenopsis. J. Jpn. Soc. Hort. Sci. 66:581-585.

Lee, N. 1991. Juvenility in Phalaenopsis. Proc. 2nd Symp. on Regulating the Production Period of Horticultural Crops. Taichung District Agr. Expt. Sta. Special Issue 23. p. 77-86.

Lee, N. and G.M. Lin. 1984. Effect of temperature on growth and flowering of Phalaenopsis white hybrid. J. Chinese Soc. Hort. Sci. 30:223-231.

Lee, N. and J.H. Lee. 1996. Changes in carbohydrates in Phalaenopsis flower induction and inflorescence development. J. Chinese Soc. Hort. Sci. 42:262275. 
Lin, Y.R. 1994. Effect of light, temperature and plant growth regulators on flowering of Phalaenopsis spp. Graduate Institute of Horticulture, National Taiwan University, Taipei, Taiwan, Master's thesis.

Lin, Y.R. and N. Lee. 1998. Light requirement of Phalaenopsis prior to and after cool-temperature forcing. J. Chinese Soc. Hort. Sci. 44:463-478.
Wang, Y.T. 1995. Gibberellic acid on Phalaenopsis. Amer. Orchid Soc. Bul. July:744-745.

Wang, Y.T. 2004. Flourishing market for potted orchids. Flower Tech. 7:2-5.

Wang, Y.T. and T.Y. Hsu. 1994. Flowering and growth of Phalaenopsis orchids following growth retardant applications. HortScience 29:285288.

Wang, Y.T., W.T. Tsai, and T.E. Dai. 2006. Heavy shading: An effective, lowcost alternative to high temperatures for inhibiting spiking in Phalaenopsis. Proc. Taiwan Intl. Orchid Symp. p.164-173. 